Revista Eletrônica de Direito Processual - REDP. Volume 16. Julho a dezembro de 2015

Periódico Semestral da Pós-Graduação Stricto Sensu em Direito Processual da UERJ

Patrono: José Carlos Barbosa Moreira. ISSN 1982-7636. pp. 77-92 http://www.e-publicacoes.uerj.br/index.php/redp/index

\title{
A CLÁUSULA DE SIGILO DA CONTESTAÇÃO NOS JUIZADOS ESPECIAS CÍVEIS ELETRÔNICOS: SUA NECESSIDADE EM NOME DO PRINCÍPIO DA IGUALDADE ${ }^{1}$
}

\section{THE PLEA OF CONFIDENTIALITY CLAUSE IN 'SMALL CLAIM'S COURTS' ELECTRONICS CASES: ITS NECESSITY ON BEHALF OF THE EQUALITY PRINCIPLE}

Caroline Gaudio Rezende

Doutoranda em Processo Civil UNESA. Mestre em Processo Civil UNESA. Juíza Leiga do Tribunal de Justiça do Estado do Rio de Janeiro. carolgaudiio_r@yahoo.com.br Diego Brainer de Souza Andre Advogado. Residente Jurídico da Procuradoria Geral do Município do Rio de Janeiro. diego_brainer@hotmail.com

RESUMO: O presente artigo vem apresentar a realidade do Juizado Especial do Tribunal de Justiça do Rio de Janeiro no que tange à necessidade de manter a contestação em sigilo nos Juizados que possuem aplicação do sistema eletrônico até o início da audiência de instrução e julgamento. O fundamento de tal necessidade tem como fulcro o princípio constitucional da igualdade, considerando, ainda, a existência de processos que até então são físicos, em que a parte autora só terá vistas dos argumentos do réu na mencionada etapa processual, nos termos da Lei n. 9.099 de 1995.

\footnotetext{
${ }^{1}$ Artigo recebido em 30/09/2015 e aprovado em 27/11/2015.
} 
Revista Eletrônica de Direito Processual - REDP. Volume 16. Julho a dezembro de 2015

Periódico Semestral da Pós-Graduação Stricto Sensu em Direito Processual da UERJ

Patrono: José Carlos Barbosa Moreira. ISSN 1982-7636. pp. 77-92 http://www.e-publicacoes.uerj.br/index.php/redp/index

PALAVRAS-CHAVE: Processo Eletrônico; Contraditório; Juizados Especiais; Direito de Defesa; Isonomia.

ABSTRACT: This article presents the reality of the "Small Claim's Courts" of Rio de Janeiro with regarding the need to keep the plea of confidential clause in answer to the complaint, in Courts which is applied the electronic system, until the start of the hearing and trial. The foundation of such need is based on the constitutional principle of equality, considering also the existence of procedures that are still physical, in that the plaintiff only has views of the arguments of the defendant in the aforementioned procedural step in accordance with the Law n. 9.099/1995.

KEYWORDS: Electronic Process; Contradictory; Small Claim's Courts; Right of Defense; Equality.

SUMÁRIO: 1. Processo Eletrônico 2. Contestação - Exercício do Direito de Defesa. 3. Contestação no Juizado - Lei 9.099/95 4. A Cláusula de Sigilo no Processo Eletrônico: a Paridade de Armas 5. Conclusão 6. Referências Bibliográficas.

\section{Processo Eletrônico}

Diante da evolução da própria sociedade, que modernamente tem grande acesso aos meios eletrônicos, o processo brasileiro passou a disciplinar a instrução processual através deste meio, havendo nitidamente duas fases temporais sobe o tema. Em um primeiro momento, hodierno ou de passagem, ocorre a sua inserção em uma fase identificada como hibrida, em que há, concomitantemente, os processos físicos com os processos eletrônicos. Após, em uma segunda fase, ocorre a substituição completa pelo processo apenas eletrônico. ${ }^{2}$

O alicerce fundamental do Juizado é a promoção do acesso à Justiça, em que, a partir da sua inserção, traz a tentativa de materialização da terceira onda renovatória do processo,

2 O TJRJ está, atualmente, em fase de ampliação do processo eletrônico, tornando as varas cíveis da Capital híbridas, sendo a intenção informatizar todos os Juizados Especiais que irão apresentar, também, este caráter. Disponível em $<$ http://portaltj.tjrj.jus.br/web/guest/servicos/processo-eletronico/relacao-normas-proc-eletronico $>$. Acesso em: 01-09-2015. 
Revista Eletrônica de Direito Processual - REDP. Volume 16. Julho a dezembro de 2015

Periódico Semestral da Pós-Graduação Stricto Sensu em Direito Processual da UERJ

Patrono: José Carlos Barbosa Moreira. ISSN 1982-7636. pp. 77-92

http://www.e-publicacoes.uerj.br/index.php/redp/index

conforme as lições de Mauro Cappelletti ${ }^{3}$. De acordo com o jurista italiano, o processo deve garantir o real acesso à Justiça (ao provimento jurisdicional), uma vez que esta acepção não está restrita a organização do Poder Judiciário na sociedade, mas a existência de instrumentos na legislação que possam tornar a Justiça efetiva para aqueles que a procuram.

Houve, portanto, uma evolução do conceito de acesso à Justiça, passando a ser entendido, à época (século XX), como a possibilidade de poder demandar perante o Poder Judiciário com mecanismos aptos na lei processual e na estrutura interna do órgão que possam garantir que o jurisdicionado venha a usufruir do comando judicial, caso contrário o acesso será tão somente de natureza formal. Isto é, sendo apenas uma previsão normativa sem resultados práticos.

Assim, ao lançar as três ondas renovatórias do processo ${ }^{4}$, aponta-se como um dos vértices da terceira a estruturação do Poder Judiciário, em que se suscita a necessidade de ocorrer um enfoque substancial ao acesso. Nesse sentido, o autor propõe um estudo crítico e uma reforma ampla de todo o aparelho estatal. ${ }^{5}$

Nesta toada, no que tange ao sistema processual brasileiro, constata-se que nas últimas décadas passou a haver uma preocupação grande do legislador e dos operadores do direito em garantir o acesso na forma descrita por Cappelletti. Tal preocupação culminou em diversas reformas na legislação processual pátria em busca do real e efetivo acesso à Justiça, ante a constatação do fenômeno denominado como a "crise do Poder Judiciário". De acordo com o I Pacto Republicano ${ }^{6}$, um dos fundamentos desta crise é a demora na prestação da cognição judicial, na qual expõe:

\footnotetext{
3 Sucintamente, Cappelletti abordar o tema do acesso à Justiça através das três ondas renovatórias, expondo: que a primeira onda é quanto à necessidade de ter mecanismos que garantam o acesso para as pessoas hipossuficientes economicamente; que a segunda onda aborda que as demandas de natureza coletiva devem ser veiculadas através de um procedimento diferenciado; e, por fim, que a terceira onda informa que o próprio Poder Judiciário deve internamente se reestruturar para que possa garantir um processo eficaz. Frise-se, ainda, a quarta onda renovatória, no sentido da necessidade de instrumentos para garantir a eficácia do processo.

4 Como evidenciado na nota retro, a primeira onda compreende o acesso aos hipossuficientes e a segunda a normatização para o processo de cunho coletivo.

5 CAPPELLETTI, Mauro; GARTH, Bryan. Acesso à Justiça. Porto Alegre: Sergio Antonio Fabris, 2002, p. 75 .

Ministério da Justiça. Reforma do Judiciário. Disponível em: $<$ http://portal.mj.gov.br/main.asp?ViewID=\%7B8E452D90\%2D6A84\%2D4AA6\%2DBBCE\%2DD6CB5D9F68 23\%7D\&params $=$ itemID=\%7B87257F27\%2D11D3\%2D4EE1\%2D930A\%2D4DC33A8DF216\%7D;\&UIPartUI $\mathrm{D}=\%$ 7B2868BA3C\%2D1C72\%2D4347\%2DBE11\%2DA26F70F4CB26\%7D > . Acesso em 02-06-2012.
} 
Revista Eletrônica de Direito Processual - REDP. Volume 16. Julho a dezembro de 2015

Periódico Semestral da Pós-Graduação Stricto Sensu em Direito Processual da UERJ

Patrono: José Carlos Barbosa Moreira. ISSN 1982-7636. pp. 77-92

http://www.e-publicacoes.uerj.br/index.php/redp/index

A morosidade dos processos judiciais e a baixa eficácia de suas decisões retardam o desenvolvimento nacional, desestimulam investimentos, propiciam a inadimplência, geram impunidade e solapam a crença dos cidadãos no regime democrático.

Por certo, a morosidade é atribuída a diversos fatores, os quais compreendem motivos de natureza jurídica e social, como, por exemplo, o aumento da procura ao Estado-Juiz e o formalismo do sistema processual conforme disciplina do CPC de 1973 em sua redação original. Tal situação está na raiz da insatisfação social em relação à prestação jurisdicional, além de outras causas igualmente relevantes.

Subsiste, desta feita, um paradoxo no acesso à Justiça brasileira, pois, embora este Poder se encontre à disposição do indivíduo sem vedações para ingresso, conforme assegurado no art. $5^{\circ}, \mathrm{XXXV}$, Constituição Federal, é preciso superar uma série de barreiras antes e durante o processo.

Nessa perspectiva, fortaleceram-se as vozes doutrinárias no direito pátrio segundo as quais o acesso à Justiça não se restringe à garantia do direito de provocação da tutela judicial. Por conseguinte, pode-se aduzir que o ordenamento jurídico pátrio se inseriu na linha do movimento mundial em prol da ampliação da concretização dos direitos, sem procrastinações, a fim de que o direito material seja plenamente respeitado e implementado.

Conforme Luiz Guilherme Marinoni ${ }^{7}$, para que o acesso à Justiça corresponda ao comando constitucional, é premente o exercício do direito de provocar o Estado e de receber a correspondente prestação de maneira efetiva e tempestiva.

Assim sendo, a partir das mencionadas reformas, reestruturaram-se alguns aspectos do Judiciário, tendo em vista torná-lo acessível materialmente ${ }^{8}$, o que se fez acompanhar de regras processuais previstas no corpo do texto constitucional, como, por exemplo, o princípio da efetividade processual ${ }^{9}$. Nessa ordem de raciocínio, preconiza-se a duração razoável do processo

7 MARINONI, Luis Guilherme. Garantia de tempestividade da tutela jurisdicional e duplo grau de jurisdição. In: TUCCI, José Rogério Cruz e (coord.). Garantias constitucionais do processo civil. São Paulo: Revista dos Tribunais, 1999, p. 218.

8 Um dos mecanismos de reestruturação foi a criação de órgãos fiscalizadores das atividades dos magistrados e do Ministério Público que estabelecem medidas para se obter uma melhor prestação destas funções da justiça, respectivamente, CNJ e CNMP. De acordo com posição do STF funcionam como órgãos externos estando este entendimento descrito na ADI n. 4.638. Disponível em: < http://www.stf.jus.br/arquivo/informativo/documento/informativo653.htm>. Acesso em 20-05-2013.

$9 \quad$ Art. $5^{\circ}$, da Constituição Federal 
Revista Eletrônica de Direito Processual - REDP. Volume 16. Julho a dezembro de 2015

Periódico Semestral da Pós-Graduação Stricto Sensu em Direito Processual da UERJ

Patrono: José Carlos Barbosa Moreira. ISSN 1982-7636. pp. 77-92 http://www.e-publicacoes.uerj.br/index.php/redp/index

e a criação de mecanismos que favoreçam a celeridade. Firmou-se um paradigma norteador das reformas subsequentes no direito processual, embora, por óbvio, celeridade não deva suplantar a própria qualidade intrínseca dos julgados exarados.

Insta salientar o respeito ao princípio corolário da formação do novel diploma processual que é o acesso à Justiça, do qual emergem os demais postulados, sendo que a celeridade e efetividade mantêm vínculos com o acesso material, tema recorrente nas pesquisas processuais nos últimos anos, haja vista os óbices para que se possa usufruir o título judicial e do direito material. Insurge-se, assim, a proposição de novo codex processual, tendo em vista a grande preocupação quanto ao tema.

A partir da constatação do panorama acima descrito, um dos instrumentos eleito nas reformas que ocorreram foi a previsão do processo eletrônico. Com a sua aplicação, pretendese coadunar racionalidade e eficiência no processo. Isto ocorre, pois, como a sua inserção tem como fundamento principal imprimir a celeridade processual, acredita-se que com as ferramentas que a informática possui haverá menor dispêndio temporal. Logo, uma efetiva prestação da Justiça de maneira satisfativa na forma prevista na legislação e apontada pela doutrina.

No ordenamento pátrio, a instrução processual através deste mecanismo ocorreu a partir da edição da lei 11.419 de 2006, que dispõe sobre a informatização do processo judicial. No entanto, cabe salientar que cada Tribunal trouxe normas procedimentais a fim de aplicar este mecanismo na sua estrutura segundo as suas peculiaridades locais. Neste contexto, podemos verificar que há Tribunais em estágio mais avançado no que concerne à distribuição por processo eletrônico, enquanto outros, como o caso do TJRJ, estão, ainda, com uma inserção mais paulatina.

Especificamente no âmbito do TJRJ, o processo eletrônico ainda está em fase de implementação e há um conjunto normativo que regula a sua aplicação. Todavia, é no sistema do Juizado Especial, objeto do presente artigo, que a sua regulação traz preocupação, tendo em

(...)

LXXVIII - a todos, no âmbito judicial e administrativo, são assegurados a razoável duração do processo e os meios que garantam a celeridade de sua tramitação. 
Revista Eletrônica de Direito Processual - REDP. Volume 16. Julho a dezembro de 2015

Periódico Semestral da Pós-Graduação Stricto Sensu em Direito Processual da UERJ

Patrono: José Carlos Barbosa Moreira. ISSN 1982-7636. pp. 77-92

http://www.e-publicacoes.uerj.br/index.php/redp/index

vista o procedimento previsto na lei infracional, como será visto mais adiante em relação à apresentação da peça contestatória e a sua disponibilização no processo.

\section{Contestação - Exercício do Direito de Defesa.}

Antes de adentar no sistema de defesa em sede de Lei 9099/95 e a incidência do processo eletrônico, faz-se necessário considerações a respeito do princípio contraditório de matriz constitucional, com previsão expressa no capítulo dos direito fundamentais e em sede internacional através do Pacto de São Jose da Costa Rica. ${ }^{10}$

Ao tratar da relevância do processo contemporâneo Ronaldo Bretâs de Carvalho Dias expõe que:

O principal alicerce do processo constitucional ou modelo constitucional do processo, considerado este a principiologia metodológica constitucional de garantia dos direitos fundamentais, deve ser entendido como um bloco aglutinante e compacto de vários direitos e garantias fundamentais inafastáveis, ostentados pelas pessoas do povo (partes), quando deduzem pretensão à tutela jurídica nos processos, perante os órgãos jurisdicionais: a)- direito de amplo acesso à jurisdição, prestada dentro de um tempo útil ou lapso temporal razoável; b)garantia do juízo natural; c)- garantia do contraditório; d)- garantia de ampla defesa, com todos os meios e recursos a ela (defesa) inerentes, aí incluído o direito à presença de advogado ou de defensor público; e)- garantia da fundamentação racional das decisões jurisdicionais, com base no ordenamento jurídico vigente (reserva legal); f)- garantia de um processo sem dilações indevidas. $^{11}$

A partir da análise de que os princípios garantem um processo justo e são verdadeiros mecanismos para a realização do processo democrático, ganha relevo especial o princípio em

\footnotetext{
10 Art $8^{\circ}$-Convenção Americana sobre Direitos Humanos (Pacto de São José da Costa Rica) 1. Toda pessoa tem direito a ser ouvida, com as devidas garantias e dentro de um prazo razoável, por um juiz ou tribunal competente, independente e imparcial, estabelecido anteriormente por lei, na apuração de qualquer acusação pena formulada contra ela, ou para que se determinem seus direitos ou obrigações de natureza civil, trabalhista, fiscal ou de qualquer outra natureza.

11 DIAS, Ronaldo Brêtas de Carvalho. Processo Constitucional e o Estado Democrático de Direito. Belo Horizonte: Del Rey, 2010, p. 125
} 
Revista Eletrônica de Direito Processual - REDP. Volume 16. Julho a dezembro de 2015

Periódico Semestral da Pós-Graduação Stricto Sensu em Direito Processual da UERJ

Patrono: José Carlos Barbosa Moreira. ISSN 1982-7636. pp. 77-92

http://www.e-publicacoes.uerj.br/index.php/redp/index

análise. Ele é apontado como o princípio basilar, pois traz a paridade das armas e a possibilidade de uma dialeticidade entre as partes quanto aos fatos levados à submissão da jurisdição estatal.

Historicamente, a garantia processual do contraditório tem a sua origem apontada na Constituição Inglesa de 1215, em que dispunha:

Nenhum homem livre será preso, aprisionado ou privado de uma propriedade, ou tornado forada-lei, ou exilado, ou de maneira alguma destruído, nem agiremos contra ele ou mandaremos alguém contra ele, a não ser por julgamento legal dos seus pares, ou pela lei da terra.

Em um primeiro momento a proteção era no sentido de oportunizar a palavra à outra parte para se defender.

Todavia, esta previsão originária e descrita na redação do dispositivo é referente ao núcleo inafastável da garantia, vez que como descreve Leonardo Greco ${ }^{12}$ todo princípio tem um mínimo de proteção. E, no caso do princípio do contraditório, essa é a sua base, seu núcleo essencial.

Desta feita, modernamente a sua concepção evoluiu apresentando duas vertentes: material e formal. O contraditório material/substancial é aquele pelo qual há o poder das partes influenciarem na decisão final. Ou seja, é a participação concreta na jurisdição. Já na vertente formal, ademais, é a interpretação literal do dispositivo (correspondente a sua origem), pelo qual é a oportunidade de as partes se manifestarem acerca das questões levantadas no processo.

No ordenamento pátrio, o contraditório está, como acima exposto, previsto como um direito de natureza fundamental positivado no art. 5, LV, CRFB. ${ }^{13}$

Constata-se que, hoje, vige o entendimento da necessidade de se levar a efeito nos sistemas jurídicos um contraditório participativo em busca da "verdade real" e não meramente formal, embora o termo em si seja rodeado de críticas epistemológicas. Ou seja, o entendimento sobre o tema não se restringe à previsão legal de que os interessados possam participar do processo.

12 GRECCO, Leonardo. Garantias Fundamentais do Processo: O Processo Justo. In: Estudos de Direito Processual. Faculdade de Direito de Campos, 2005, p. 20.

13 "Aos litigantes, em processo judicial ou administrativo, e aos acusados em geral são assegurados o contraditório e ampla defesa, com os meios e recursos a ela inerentes." 
Revista Eletrônica de Direito Processual - REDP. Volume 16. Julho a dezembro de 2015

Periódico Semestral da Pós-Graduação Stricto Sensu em Direito Processual da UERJ

Patrono: José Carlos Barbosa Moreira. ISSN 1982-7636. pp. 77-92 http://www.e-publicacoes.uerj.br/index.php/redp/index

Assim, conforme esclarecimento de Leonardo José Carneiro da Cunha ${ }^{14}$, o princípio não é apenas o direito de informação, reação ou influência. O contraditório pleno é aquele pelo qual o interessado precisa participar do debate, fornecendo os elementos à realização plena de seus direitos, o que inclui:

a) o direito de ser ouvido; (b) o direito de acompanhar os atos processuais; (c) o direito de produzir provas; (d) o direito de ser informado regularmente dos atos praticados no processo; (e) o direito à motivação das decisões; (f) o direito a impugnar decisões judiciais.

Afirma Dierle Nunes que:

O contraditório constitui um verdadeira garantia de não surpresa que impõe ao juiz o dever de provocar o debate acerca de todas as questões, inclusive as de conhecimento oficioso, impedindo que em 'solitária onipotência' aplique normas ou embase a decisão sobre fatos completamente estranhos à dialética defensiva de uma ou de ambas as partes. Ocorre que a decisão de surpresa deve ser declarada nula, por desatender ao princípio do contraditório. Toda vez que o magistrado não exercitasse ativamente o dever de advertir as partes quanto ao específico objeto relevante para o contraditório, o provimento seria invalidado, sendo que a relevância ocorre se o ponto de fato ou de direito constituiu necessária premissa ou fundamento para a decisão (ratiodecidendi). Assim, o contraditório não incide sobre a existência de poderes de decisão do juiz, mas, sim, sobre a modalidade de seu exercício, de modo a fazer do juiz um garante da sua observância e impondo a nulidade de provimentos toda vez que não exista a efetiva possibilidade de seu exercício. [....] Para a demonstração cabal do atual perfil comparticipativo que o princípio possui em sua releitura democrática, faz-se necessária a análise pormenorizada do já aludido fenômeno intitulado "decisão de surpresa" [...] que atribui a nulidade de decisões fundadas sobre a resolução de questões de fato e de direito não submetidas à discussão com as partes e não indicadas preventivamente pelo juiz. ${ }^{15}$

\footnotetext{
14 CUNHA, Leonardo José Carneiro da. O processo civil no Estado Constitucional e fundamentos do projeto brasileiro. In: Revista de Processo. São Paulo: Revista dos Tribunais, 2012, julho, n. 209, p. 360.

15 NUNES, Dierle. Processo jurisdicional democrático: uma análise critica das reformas processuais. Curitiba: Juruá, 2008, p. 60.
} 
Revista Eletrônica de Direito Processual - REDP. Volume 16. Julho a dezembro de 2015

Periódico Semestral da Pós-Graduação Stricto Sensu em Direito Processual da UERJ

Patrono: José Carlos Barbosa Moreira. ISSN 1982-7636. pp. 77-92

http://www.e-publicacoes.uerj.br/index.php/redp/index

Esse posicionamento encontra respaldo, ainda, na interpretação de Humberto Theodoro

Junior $^{16}$, quando ressalta que o debate jurídico fica enriquecido quando se traz à baila a concepção do contraditório participativo. Como se pode notar, ampla doutrina, portanto, defende o contraditório nessa perspectiva, que, diga-se de passagem, encontrará notável respaldo com o advento do Novo Código de Processo Civil ${ }^{17}$, referindo-se explicitamente a efetivo contraditório.

Adicionalmente, ao propiciar uma justiça célere, o Juizado não está imune destas inferências, em virtude da própria unicidade do sistema jurídico e da força normativa da Constituição. Sob esse viés, é mandatório manter íntegro o respeito ao princípio do contraditório e aos demais princípios correlatos com a aplicação do processo justo, participativo e democrático também nesta sede.

\section{Contestação no Juizado - Lei 9099/95}

Os Juizados Especiais encontram-se positivados em sede constitucional ${ }^{18}$, estando determinada a sua competência conforme disposto no art. 98, inciso I, da Constituição Federal, para causas de menor complexidade em âmbito cível. ${ }^{19}$

Em breves linhas, o Juizado Especial ${ }^{20}$ está inserido na terceira onda renovatória de Cappelletti, - acima indicada, a qual tem por objetivo através de regras procedimentais próprias e diferenciadas aproximar o Judiciário da sociedade. Nesse sentido, de acordo com o seu

16 THEODORO JÚNIOR, Humberto; NUNES, Dierle José Coelho. Uma dimensão que urge reconhecer ao contraditório no direito brasileiro: sua aplicação como garantia de influência, de não surpresa e de aproveitamento da atividade processual. In: Revista de Processo. São Paulo: Revista dos Tribunais, 2009, fevereiro, n. 168, p. 120. $17 \quad$ Lei 13.105, de 16 de março de 2015, Art. 7o : "É assegurada às partes paridade de tratamento em relação ao exercício de direitos e faculdades processuais, aos meios de defesa, aos ônus, aos deveres e à aplicação de sanções processuais, competindo ao juiz zelar pelo efetivo contraditório."

18 Anteriormente havia o Juizado de Pequenas Causas regulado em lei própria de n ${ }^{0}$ 7.244/1984.

19 Art. 98. A União, no Distrito Federal e nos Territórios, e os Estados criarão:

I - juizados especiais, providos por juízes togados, ou togados e leigos, competentes para a conciliação, o julgamento e a execução de causas cíveis de menor complexidade e infrações penais de menor potencial ofensivo, mediante os procedimentos oral e sumariíssimo, permitidos, nas hipóteses previstas em lei, a transação e o julgamento de recursos por turmas de juizes de primeiro grau.

20 Atualmente, é um microssistema composto por três legislações dirigidas a três áreas de atuação: para demandas estaduais de natureza cível e penal (lei 9099/95); demandas de competência da Justiça Federal (lei $n^{\circ}$ 10.259/20001) e matérias relacionadas com a Fazenda Pública (Lei n ${ }^{\circ} 12.153 / 2009$ ). 
Revista Eletrônica de Direito Processual - REDP. Volume 16. Julho a dezembro de 2015

Periódico Semestral da Pós-Graduação Stricto Sensu em Direito Processual da UERJ

Patrono: José Carlos Barbosa Moreira. ISSN 1982-7636. pp. 77-92 http://www.e-publicacoes.uerj.br/index.php/redp/index

idealizador, é necessário um tratamento diferenciado para determinadas demandas que possuem menor complexidade com meios acessíveis e efetivos. ${ }^{21}$

Para tanto, na linha do que fora proposto pelo jurista há a constituição de um procedimento que é formado por um núcleo de princípios que de certa forma relativizam o formalismo processual (oralidade, simplicidade, informalidade, economia processual e celeridade etc. ${ }^{22}$ ), tornando o processo mais compreensível para os indivíduos que buscam a tutela jurisdicional e, concomitantemente, propiciando duração mais célere a partir da supressão de determinadas formalidades prevista no processo tradicional.

No que tange à criação deste órgão no ordenamento pátrio, expõe Leonardo Greco ${ }^{23}$ que a inovação "representou uma das mais aplaudidas reformas da administração da Justiça brasileira, pelo impacto positivo que teve na facilitação do acesso à Justiça para milhões de cidadãos".

Em relação especificamente ao contraditório, a lei foi silente no tocante ao momento processual para a apresentação da defesa, pois não estabeleceu um prazo para tanto. No entanto, a doutrina regulou o tema estabelecendo que a mesma ocorre em até Audiência de Instrução de Julgamento, conforme Enunciado Cível $\mathrm{n}^{\circ} 10$ editado pelo FÓRUM NACIONAL DE JUIZADOS ESPECIAIS. ${ }^{24}$ Assim sendo, tendo em vista que comumente esta regra é adotada, na maioria das vezes o autor só possui o acesso ao conteúdo da defesa neste momento processual, pois em sede de AIJ o réu apresenta a contestação com o encarte dela nos autos.

Todavia, a partir da regulamentação do processo eletrônico esta situação vem sendo esvaziada, posto que devido à possibilidade de convolação imediata em AIJ o réu já faz de imediato a apresentação da sua peça de bloqueio com a sua representação processual antes mesmo do momento da designação da referida audiência. Esta situação merece ser observada com o devido cuidado.

\footnotetext{
21 CAPPELlETTI, Mauro; GARTH, Bryan. Acesso à Justiça. Porto Alegre: Sergio Antonio Fabris, 2002 , p. 94-99.

22 Essa é a literalidade do art. 2 da Lei 9.099 de 1995 (Lei dos Juizados Especiais Cíveis), que dispõe: “ $O$ processo orientar-se-á pelos critérios da oralidade, simplicidade, informalidade, economia processual e celeridade, buscando, sempre que possivel, a conciliação ou a transação."

23 GRECO, Leonardo. Instituições de Processo Civil. Rio de Janeiro: Forense, 2010. vol. II, p. 441.

24 ENUNCIADO 10 - A contestação poderá ser apresentada até a Audiência de Instrução e Julgamento.
} 
Revista Eletrônica de Direito Processual - REDP. Volume 16. Julho a dezembro de 2015

Periódico Semestral da Pós-Graduação Stricto Sensu em Direito Processual da UERJ

Patrono: José Carlos Barbosa Moreira. ISSN 1982-7636. pp. 77-92 http://www.e-publicacoes.uerj.br/index.php/redp/index

No que tange à realidade do Tribunal de Justiça do Rio de Janeiro em sede de Juizados no processo eletrônico, a contestação normalmente não é anexada aos autos no momento do ato da audiência, pois deve ser protocolizada anteriormente via identificação eletrônica pelo próprio advogado. Logo, para impedir a preclusão temporal e por via de consequência a decretação da revelia o réu a deixa disponível para acesso de terceiros com os documentos de representação ${ }^{25}$ tão logo ciente da demanda, desde que o réu anua com isso.

A questão se torna controversa no momento que há um tratamento diferenciado entre os processos submetidos ao processo eletrônico e físico, pois há em relação ao primeiro um eventual beneficio no qual o outro não terá em relação ao conhecimento das partes quanto ao conteúdo da defesa. No processo eletrônico, o autor mediante a disponibilização da contestação no processo virtual tem ciência dos fatos narrados. Em contrapartida, a parte que está submetida ao processo físico só terá acesso no momento da AIJ.

A diferença de tratamento e as suas consequências se tornam mais evidentes com a apresentação no processo eletrônico de impugnação escrita à peça da parte ré, ainda que não haja o pedido contraposto (o que não é raro em sede de JEC). Ressalte-se, ainda, que mediante o acesso prévio o autor pode anexar provas para desconstituir as alegações da parte ré - de outro lado, outro jurisdicionado em situação idêntica, no processo físico, não poderá fazê-lo.

Há que se ressaltar, ainda, que, por meio do conhecimento antecipado das alegações constantes da defesa, tem-se a oportunidade de a parte autora, mediante análise prévia dos argumentos da parte ré, melhor instruir o processo, bem como sua peça inaugural com novos argumentos (realizando uma emenda às avessas) - situação que não se vislumbra nos processos físicos.

Não se quer questionar a legalidade per si de apresentação de impugnação escrita às alegações do réu, como se fizesse as vezes de uma réplica, eis que regido o sistema dos Juizados pelos princípios da informalidade e outros. Além disso, a impugnação escrita prestigia o próprio ideário de contraditório substancial tão festejado pela doutrina, bem com a busca da "verdade real”. Porém, o jurisdicionado do processo físico não pode ser tratado desigualmente, quando

25 Resolução 16/2009 TJRJ. Disponível em: <http://webfarm.tjrj.jus.br/biblioteca/index.html>. Acesso em: 01-09-2015 
Revista Eletrônica de Direito Processual - REDP. Volume 16. Julho a dezembro de 2015

Periódico Semestral da Pós-Graduação Stricto Sensu em Direito Processual da UERJ

Patrono: José Carlos Barbosa Moreira. ISSN 1982-7636. pp. 77-92 http://www.e-publicacoes.uerj.br/index.php/redp/index

em condição idêntica com aquele que litiga em processo eletrônico. Há, então, uma situação de antijuridicidade temporária, até a implantação integral do processo eletrônico.

Frise-se que a questão de se ter vista à contestação apenas na AIJ não deixa de ser problemática, pois, em alguns casos de maior complexidade (observados os limites dos Juizados) ou por próprio excesso de zelo do causídico e outros eventuais problemas, há defesas fartas, com muitas páginas, praticamente impassíveis de serem analisadas em parcos lapsos temporais, ao mais das vezes diante da pressão sobre o advogado da parte autora sendo questionado se há alguma impugnação oral a realizar. Isso, por certo, deve ser combatido, mas não por meio de tratamentos diferenciados.

Tudo isso corrobora a violação à isonomia que ora alegada. Ademais, sem desconsiderar que do ponto de vista principiológico o contraditório substancial deve ser entendido em seu conteúdo finalístico enquanto mandado de otimização, a matéria merece leitura atenta à luz do princípio constitucional da isonomia, havendo a necessidade de ocorrer verdadeira compatibilização. Entendimento contrário levaria a tratamento distinto do jurisdicionado em razão da própria sorte dos critérios de competência e andamento da implementação do processo eletrônico.

Por assim exposto, sabendo-se que ao contrário das regras, que são normas binárias, aplicadas segundo a lógica do tudo ou nada, os princípios têm uma dimensão de peso e são aplicados em maior ou menor grau, conforme juízos de ponderação formulados tendo em vista outros princípios concorrentes e eventuais limitações, devendo-se, até então, privilegiar a isonomia. Almeja-se, apenas, então, que, durante o mencionado hibridismo passageiro do processo físico ao processo eletrônico nos Juizados, seja garantida a igualdade entre ambos.

\section{A Cláusula de Sigilo no Processo Eletrônico: a Paridade de Armas}

A noção de isonomia ${ }^{26}$ está intrinsecamente ligada à de segurança jurídica. Tem por fim levar a efeito o tratamento igualitário a todos que se encontrem na mesma situação jurídica.

26 A concepção de igualdade se forma com Aristóteles e ganha força com a Revolução Francesa. No Brasil ela ganha importância a partir do lecionado por Rui Barbosa ao expor: "A regra da igualdade não consiste senão em quinhoar desigualmente aos desiguais, na medida em que se desigualam. Nesta desigualdade social, proporcionada à desigualdade natural, é que se acha a verdadeira lei da igualdade... Tratar com desigualdade a 
Revista Eletrônica de Direito Processual - REDP. Volume 16. Julho a dezembro de 2015

Periódico Semestral da Pós-Graduação Stricto Sensu em Direito Processual da UERJ

Patrono: José Carlos Barbosa Moreira. ISSN 1982-7636. pp. 77-92 http://www.e-publicacoes.uerj.br/index.php/redp/index

A concepção de igualdade se forma com Aristóteles e ganha força com a Revolução

Francesa. No Brasil ela ganha importância a partir do lecionado por Rui Barbosa ${ }^{27}$ ao expor:

A regra da igualdade não consiste senão em quinhoar desigualmente aos desiguais, na medida em que se desigualam. Nesta desigualdade social, proporcionada à desigualdade natural, é que se acha a verdadeira lei da igualdade... Tratar com desigualdade a iguais, ou a desiguais com igualdade, seria desigualdade flagrante, e não igualdade real.

Luiz Guilherme Marinoni ${ }^{28}$ assinala que a isonomia tem como um de seus vieses a noção de ser interpretada como sinônimo de igualdade na realização dos atos internos do andamento processual.

A observação do postulado tem importância devido à necessidade de observação do processo justo. Este é o ideário que zela pela proteção integral dos direitos e das garantias constitucionais, o que inclui a aplicação das regras processuais, à luz das disposições constitucionais. Segundo análise de Eduardo Cambi, é pertinente acrescentar o que segue:

ii) a observância das garantias compreendidas na cláusula do devido processo legal; iii) a participação dialética na formação do convencimento do juiz, que irá julgar a causa (efetividade do contraditório); iv) a adequada e tempestiva análise, pelo juiz, natural e imparcial, das questões discutidas no processo (decisão justa e motivada); v) a construção de técnicas processuais adequadas à tutela dos direitos materiais (instrumentalidade do processo e efetividade dos direitos). ${ }^{29}$

Com base nestas observações, quanto ao princípio da igualdade é necessária a presença da cláusula de sigilo ${ }^{30}$ aos processos eletrônicos em âmbito do Juizado. A sua necessidade se mostra imperiosa, pois caso contrário não haveria a observação do postulado da igualdade

\footnotetext{
iguais, ou a desiguais com igualdade, seria desigualdade flagrante, e não igualdade real.” BARBOSA, Rui. Oração aos moços, $\quad$ p. $40 . \quad$ Disponível $<$ http://www.casaruibarbosa.gov.br/dados/DOC/artigos/rui_barbosa/FCRB_RuiBarbosa_Oracao_aos_mocos.Pdf >. Acesso em: 02-05- 2013.

27 BARBOSA, Rui. Oração aos moços, p. 40. Disponível em: Disponível em: http://www.casaruibarbosa.gov.br/dados/DOC/artigos/rui_barbosa/FCRB_RuiBarbosa_Oracao_aos_mocos.Pdf $>$. Acesso em: 02-05- 2013.

28 MARINONI, Luiz Guilherme; MITIDIERO, Daniel. Código de Processo Civil comentado artigo por artigo. São Paulo: Revista dos Tribunais, 2008, p. 23.

${ }_{29}$ CAMBI, Eduardo. Neoconstitucionalismo e neoprocessualismo. Vitória: Panóptica, 2007, fevereiro, ano 1, n. 6, p. 24-25. Disponível em: <http//:www.panoptica.org>. Acesso em 02-09-2012.

30 A Cláusula de Sigilo é o instrumento que o Tribunal de Justiça do Rio de Janeiro utiliza para manter a peça de bloqueio indisponível até o momento de início da Audiência de Instrução e Julgamento.
} 
Revista Eletrônica de Direito Processual - REDP. Volume 16. Julho a dezembro de 2015

Periódico Semestral da Pós-Graduação Stricto Sensu em Direito Processual da UERJ

Patrono: José Carlos Barbosa Moreira. ISSN 1982-7636. pp. 77-92 http://www.e-publicacoes.uerj.br/index.php/redp/index

material entre as partes (garantia esta de ordem constitucional), vez que jurisdicionados em igual situação irão possuir tratamento diferente em um mesmo ato processual quanto à possibilidade de manifestação ou não da contestação da parte ré e ciência das impugnações realizadas.

A existência desta cláusula impede esta situação e, assim, deve ter aplicação cogente para que todos que estejam submetidos ao regime do Juizado Especial possam ter as mesmas "armas" processuais para apresentação de eventuais ataques pela parte ré, em virtude da própria força normativa da Constituição. Autorizar o oposto, ainda que em nome do contraditório, leva ao desiquilíbrio do sistema do Juizado. Desta feita, a mencionada cláusula tem por fim trazer e realizar a garantia de um princípio de ordem constitucional e promoção do processo civil constitucional.

\section{Conclusão}

Assim, por todo o exposto, o presente artigo pretende demonstrar que enquanto houver concomitantemente processos na forma física e eletrônica em sede de Juizado Especial Cível é necessária a existência da cláusula de sigilo, como hoje se oportuniza no TJRJ para o réu no momento da disponibilização da sua peça, para que não ocorra violação ao postulado constitucional da isonomia. Entretanto, esta cláusula não deve ser uma opção, mas sim uma regra geral a todos que estão submetidos ao JEC.

A eventual supressão desta regra, viabilizando, desta feita, o acesso à contestação desde o momento da audiência de conciliação ou até antes só pode ser eventualmente viável quando houver a inteira aplicação do processo eletrônico no sistema dos Juizados, vez que inexistiria tratamento diferenciado aos jurisdicionados submetidos ao mesmo procedimento legal.

Em que pese a facilitação inegável na prática processual em relação à ciência prévia quanto aos termos da peça de bloqueio, por enquanto, há situação de antijuridicidade manifesta em tal modus operandi, não devendo prevalecer em face do postulado da isonomia. $\mathrm{Na}$ ponderação de interesses há uma prevalência da igualdade material, em nome do processo justo e democrático que deve guiar o ordenamento jurídico pátrio.

\section{REFERÊNCIAS BIBLIOGRÁFICAS}


Revista Eletrônica de Direito Processual - REDP. Volume 16. Julho a dezembro de 2015

Periódico Semestral da Pós-Graduação Stricto Sensu em Direito Processual da UERJ

Patrono: José Carlos Barbosa Moreira. ISSN 1982-7636. pp. 77-92 http://www.e-publicacoes.uerj.br/index.php/redp/index

BAPTISTA DA SILVA, Ovídio. Democracia Moderna e Processo civil. In: GRINOVER, Ada Pellegrini; DINAMARCO, Cândido; WATANABE, Kazuo (org.). Participação e Processo. São Paulo: Revista dos Tribunais, 1988.

BARBOSA MOREIRA, José Carlos. Os poderes do juiz na direção e na instrução do processo. Revista Brasileira de Direito Processual, Uberaba, Forense, v. 15, n. 59, p. 131-138, jul./set. 2007. p. 137

BARBOSA, Rui. Oração aos moços, p. 40. Disponível em: Disponível em: http://www.casaruibarbosa.gov.br/dados/DOC/artigos/rui_barbosa/FCRB_RuiBarbosa_Oraca o_aos_mocos.Pdf>.Acesso em: 02-05- 2013.

CAMBI, Eduardo. Neoconstitucionalismo e neoprocessualismo. Vitória: Panóptica, 2007, fevereiro, ano 1, n. 6. Disponível em: <http//:www.panoptica.org>. Acesso em 02-09-2012.

CAPPELlETTI, Mauro; GARTH, Bryan. Acesso à Justiça. Porto Alegre: Sergio Antonio Fabris, 2002.

CAPPELLETTI, Mauro. O acesso à justiça e a função do jurista em nossa época. Revista de Processo. São Paulo: Editora Revista dos Tribunais, n. ${ }^{\circ}$ 61, p. 148-9, 1991. CARNEIRO, Paulo Cesar Pinheiro. Acesso à justiça: juizados especiais e ação civil pública: uma nova sistematização da teoria geral do processo. Rio de Janeiro: Forense, 2007.

DIAS, Ronaldo Brêtas de Carvalho. Processo Constitucional e o Estado Democrático de Direito. Belo Horizonte: Del Rey, 2010.

DIDIER JÚNIOR, Fredie. O principio da cooperação: uma apresentação. Revista de Processo, São Paulo, rev. dos tribunais, n. 127, p. 75-79, set, 2005.

GRECO Leonardo. Garantias Fundamentais do Processo: O Processo Justo. In: Estudos de Direito Processual. Campos dos Goytacazes: Faculdade de Direito de Campos, 2005.

LUCON, Paulo Henrique dos Santos. Duração razoável e informatização do processo nas recentes reformas. Disponível em: $<$ http://www.arcos.org.br/periodicos/revista-eletronica-dedireito-processual/volume-vi/duracao-razoavel-e-informatizacao-do-proceso-nas-recentesreformas $>$. Acesso em: 13-04-2013.

Ministério da Justiça. Reforma do Judiciário. Disponível em: < http://portal.mj.gov.br/main.asp?ViewID=\%7B8E452D90\%2D6A84\%2D4AA6\%2DBBCE\% 
Revista Eletrônica de Direito Processual - REDP. Volume 16. Julho a dezembro de 2015

Periódico Semestral da Pós-Graduação Stricto Sensu em Direito Processual da UERJ

Patrono: José Carlos Barbosa Moreira. ISSN 1982-7636. pp. 77-92 http://www.e-publicacoes.uerj.br/index.php/redp/index

2DD6CB5D9F6823\%7D\&params=itemID=\%7B87257F27\%2D11D3\%2D4EE1\%2D930A\%2 D4DC33A8DF216\%7D;\&UIPartUID=\%7B2868BA3C\%2D1C72\%2D4347\%2DBE11\%2DA 26F70F4CB26\%7D>. Acesso em 02-06-2012.

MARINONI, Luiz Guilherme; Mitidiero, Daniel. O projeto do $C P C$ : críticas e propostas. São Paulo: Revista dos Tribunais, 2010.

NUNES, Dierle José Coelho. Processo constitucional contemporâneo. In: THEODORO JR., Humberto et al. (Coord.). Processo e constituição: os dilemas do processo constitucional e dos princípios processuais constitucionais. Rio de Janeiro: GZ, 2010.

. Processo jurisdicional democrático: uma análise crítica das reformas processuais. Curitiba: Juruá, 2009.

SARLET, Ingo Wolfgang. A eficácia do direito fundamental à segurança jurídica: dignidade da pessoa humana, direitos fundamentais e proibição de retrocesso social no direito constitucional brasileiro. In: Revista Brasileira de Direito Público - RBDP, Belo Horizonte, ano 3, n. 11, out/dez 2005.

THEODORO JUNIOR, Humberto; NUNES, Dierlei José Coelho. Uma dimensão que urge reconhecer ao contraditório no direito brasileiro: sua aplicação como garantia de influência, de não surpresa e de aproveitamento da atividade processual. In: Revista de Processo. São Paulo: Revista dos Tribunais, 2009, fevereiro, n. 168. 